\title{
A Too-Future Eschatology? The Limits of the Phenomenology of Liturgy in Jean-Yves Lacoste
}

https://doi.org/10.1515/opth-2019-0028

Received May 04, 2019; accepted September 06, 2019

\begin{abstract}
The article first outlines Jean-Yves Lacoste's phenomenological description of "liturgy", i.e. the encounter between God and the human being. It argues that Lacoste's rejection of the religious apriori on the side of the human being and emphasis on God's transcendence and otherness leads to decontextualization of the experience of Christian faith, as his strongly future eschatology does not allow for the real transformation of both the individual and social lives of believers. In the second step, the article gives two counterexamples to Lacoste's attitude that represent an attempt to recontextualize the experience of Christian faith within concrete historical and cultural coordinates. The examples come from the work of American theologian William Cavanaugh and Czech philosopher Robert Kalivoda, whose focus lies in the hermeneutics of a sacramental experience and the question of the history-making of Christian faith. Cavanaugh recontextualizes the understanding of the sacramental experience in terms of globalization. Kalivoda interprets the transformation of Christian eschatological ideas into a program of real social changes with special attention devoted to the Hussite revolution of the 15th century and the Hussite conception of the Lord's Supper. The article concludes that Kalivoda's emphasis on present eschatology stands in opposition to Lacoste's emphasis on future eschatology, whereas Cavanaugh holds a middle position with balanced emphasis on both poles of Christian eschatology.
\end{abstract}

Keywords: eschatology; sacramental experience; millennialism; phenomenology; liturgy; Jean-Yves Lacoste; William Cavanaugh; Robert Kalivoda

The work of French theologian and philosopher Jean-Yves Lacoste uses phenomenological methodology to examine the possibilities of the human experience with God. Lacoste does not call this experience "religious", for this notion, since Schleiermacher, has been understood in terms of "feeling" and, according to the French thinker, this is inappropriate for the reality of the encounter between the human being and God. Instead of religious experience, Lacoste speaks of "liturgy", which designates "the logic that presides over the encounter between God and man writ large"1 and exceeds the limits of worship. And because "the supposed border" between theology and philosophy "tends to disappear" in Lacoste's thought, ${ }^{2}$ we find here a powerful and fresh introduction of terms such as "liturgy" or "vigil" into the field of phenomenological philosophy. I want to briefly outline Lacoste's phenomenological description of liturgy and then examine a certain limit of his conception stemming from the emphasis placed on God's otherness and the future eschatology. I find the major flaw of Lacoste's attitude towards the encounter of God and human being in the decontextualization of the experience of Christian faith: believers find

1 Lacoste, Experience and the Absolute, 2.

2 Ibid.

*Corresponding author: Jan Černý, University of Hradec Králové, Hradec Králové, Czech Republic; E-mail: jcerny540@gmail.com 
themselves outside of the broader cultural and historical context in the "liturgy" because Lacoste's strongly future eschatology does not allow for the real transformation of both their individual and social lives. In the second step I will give two counterexamples of an attitude that tries to recontextualize the experience of Christian faith within the concrete historical and cultural coordinates. These two counterexamples come from the work of American theologian William Cavanaugh and Czech philosopher Robert Kalivoda. I will demonstrate the difference between these two thinkers and Lacoste in their respective conceptions of the hermeneutics of the sacramental experience and their respective treatment of the question of the historymaking of Christian faith, as the encounter of God and human being - the prominent example of which is the sacramental experience - has always been shaping human history.

\section{The phenomenology of liturgy}

The grounding work of Lacoste's phenomenology of liturgy is his book from 1994, Experience and the Absolute, in which he develops his insights in a fruitful dialogue with the philosophy of Martin Heidegger. ${ }^{3}$ Lacoste follows Heiddegger's imposing reorganization of the question of human being and begins his survey with the examination of one's "place" and of the "world" as a complex transcendental structure of human experience. Lacoste goes even further than his philosophical master: not only he accepts the necessity to think - whenever we think of human beings - from within space and time, from within the limits of a world (In-der-Welt-sein), but he also raises the question, not really posed in Being and Time, as to whether our inherence in the world fundamentally has to do with consciousness, which he answers in the negative. He insists that "the world has already taken possession of Dasein prior to any conscious action or awareness. 'Open' to the world, Dasein cannot, in this respect, avail itself of any form of protection from it." ${ }^{4}$ Consciousness reflects, which is why it does not bear any constitutive function, it does not ground the world. Consciousness does not, according to Lacoste, create the opening (Erschlossenheit) of Dasein; on the contrary, this opening is first the condition for the exercise of consciousness. The place takes sovereignty, in the form of the world, over the I - and Lacoste concludes that subverting one's relation to place in the name of a relation with the "transcendent" Absolute is to be judged as a surprising conduct. In this way Lacoste finds his first premise: Being-in-the-world means for Dasein an atheistic existentialism. The second is grounded in the important shift which took place in Heidegger after his reading of Hölderlin, in the lectures given in 1934-1935 and in the treatise The Origin of the Work of Art. Human beings live not only in the world, being is meted out by the interaction of the four terms: the "earth", the "sky", "mortals" and "deities". Over this "Fourfold" the sacred reigns sovereign, even over the gods themselves. The human being now lives in peace on the "earth" in the midst of the "Fourfold" (or more precisely in the dialectics of "world" and "earth"), in proximity to gods - and this serene dwelling on the earth Lacoste judges to be an existential paganism, as the pagan moment of facticity. Neither the existential atheism of the "world" nor the immanent numinous secret of the "earth" are the liturgical experiences of the Absolute, who is someone and who promises a relation with us.

So what do we need, according to Lacoste, for an encounter with the transcendent Absolute? First we need to be redirected - from every satisfaction in the world or on the earth - by a "restlessness", as classicly formulated in the incipit of Augustine's Confessions; restlessness points to the eschatological satisfaction that, by definition, the Absolute alone promises. This immemorially present restlessness must then be informed by the knowledge that the Absolute is a person and that $\mathrm{s} /$ he promises a forgiving relation with us. Liturgy is an act of a free will, bracketing the world and earth that are the transcendental conditions of our experience. Liturgy is an act of transgression. Lacoste spends a lot of energy distinguishing the initial, transcendental conditions of our existence from the "originary" condition of the non-possession of our selves. The initial is ambiguous, uniting the practical atheism of Dasein with the paganism of "earthly" experience and, as such, represents a divertissement, the forgetting of the originary conditions of human

3 Here I follow my review of Lacoste’s book: Černý, "Experience and the Absolute”.

4 Lacoste, Experience and the Absolute, 11. 
life, which are those of disappropriation - the human being is, at least at the hours of birth and death, absolutely poor and removed from any appropriation, depending on the gift of being; at the origin the self is not self-positing but is given to itself - and forgetting of God. Liturgy is then the violence done to the transcendental conditions of our existence, the divertissement of the initial divertissement.

Lacoste unites his phenomenological description of what happens when people pray with two basic notions: that of the night (this being inspired by John of the Cross), and that of the "next to last" (Bonhoeffer). The "night" is a metaphor for two things: first, we try to submit our being-in-the-world to being-in-vocation in the vigil, we give the Absolute the time we could give to the sleeping, which is why liturgy does not mean an escape from the exigencies of daily life; ethics and liturgy are, for Lacoste, two poles of one structure, of a critique of the provisional in the name of the eschatological. The Absolute and the liturgy are not necessary; God is not the ontotheological foundation of the world, God comes from beyond-necessary, Lacoste argues, in agreement with Jüngel. ${ }^{5}$ The second meaning of the metaphor of night rests on what Lacoste calls "non-experience" and "nonevent": liturgy has fundamentally a non-experiential character, the presence of the Absolute can never be verified this side of death, the contents of consciousness can never be unambiguously connected with God's descent. This does not hinder us from wanting to know the Absolute in the form of affective knowledge (connaissance affective) but this knowledge need not confirm conceptual knowledge (savoir conceptuel) - in the field of liturgy, knowledge exceeds feeling (with its ambiguity). ${ }^{6}$ In the end, Lacoste unites the nonexperience of liturgy with the Cross in the notion of anthropologia crucis: Christ's cross is a revelation of a "minimal man", of a person bereft of any appropriation. The Cross as a place of nonexperience teaches us that God can be closest to us even though the senses know him only as an absence. Only the Cross can make our nonexperience meaningful, can bring the paradoxical joy. "[T]he paradoxical joy that is born of humiliation may be the fundamental mood of preeschatological experience." The "next to last" is this preeschatological. Liturgy brings humanity to a twofold distance, from the initial conditions of its existence (from the atheism of the "world" and the paganism of the "earth"), but at the same time manifests its distance from the definitive realities of the eschaton. The human person exists "from the future onward" in the liturgy but this absolute future is not fully realized yet; we are aware of our reconciliation with the Absolute (or, more precisely, of God's reconciliation with us), but we are not yet really self-identical: our mode of being is preeschatological. Liturgy does not bring about our transformation: in it we are facing God only in anticipation.

\section{Negative anthropology}

The striking feature of Lacoste's phenomenology of liturgy is its negativity: The negative vocabulary of "nonplace", "nonevent" or "nonexperience" leads to a rather negative anthropology. We are not (yet) selfidentical this side of death; our real home is the reality of the eschaton but we have not (yet) arrived there. God is the transcendent Other, and their presence in our life, considered by Lacoste phenomenologically as a life of consciousness, can never be verified. From the phenomenological point of view, God's transcendence is precisely Husserl's famous extra-worldly "divine", "something transcendent in a sense totally different from that in which the world is something transcendent". ${ }^{8}$ This extra-wordly divine, of course, is included in the phenomenological reduction in Husserl; as a theological counterpart to this Husserlian reduction, Lacoste proposes "a liturgical reduction" (or "theological" or "eschatological" reduction in his first book, Note sur le temps) that brackets the profanity of the world and opens a believer to facing the transcendent Absolute. ${ }^{9}$ Yet even this reduction does not transform the divine transcendence into immanence. Although the liturgical reduction is driven by the eschatological reality, it does not bring about the eschatological

\footnotetext{
5 See Lacoste, Experience and the Absolute, 81.

6 See Ibid., 144.

7 Ibid., 194.

8 Husserl, Ideas I, 134.

9 See Lacoste, Experience and the Absolute, 174.
} 
transfiguration, and the condition of the believer remains preeschatological. ${ }^{10}$ The liturgical reduction serves mainly as a critical tool in Lacoste's writings. It challenges our inclination to possess, to dwell in the world in a mode of possession; as such, it is yet another feature of Lacoste's rather negative anthropology. It is true that the theological imagination of Note sur le temps finds, alongside this criticism of our beingin-the-world, something more positive for the believer: the theological reduction brings about a "play" in the relation of the believer to the world, a play in which the rules of the world are still valid but the pace of the believer becomes that of a ropewalker. This new pace is different from the secular one although it, too, obeys the law of gravity. Or, the sacrament permits "the eschatological reduction", in which the definitive reality becomes transparent for us. ${ }^{11}$ But overall, even after all these reductions are made, we perceive only a sketch of things to come, our existence is still incomplete and not really transformed, either in the vertical sense of becoming closer to God, or in the horizontal sense of seeing earthly things differently.

This lack of transformation on the side of the believer is, to me, the main limit of the phenomenology of liturgy in Jean-Yves Lacoste. The transformation is the work of God's grace in the understanding of Scripture and Christian theology. It is the work of grace that makes the believer participate in the reality of God's kingdom and even in God's nature. Grace sets the baptized believer in the sphere of Trinity and its "economy", in the sphere of God's salvation: "God raised us up with Christ and seated us with him in the heavenly realms in Christ Jesus" (Ef 2:6); whoever hears Jesus' word and believes him "has passed from death to life" (J 5:24); a believer "participates in the divine nature" (2 P 1:4). The Apostle Paul writes to his fellow Christians that "Christ is in you" (R 8:10) and that believers "are in Christ Jesus" (1 Kor 1:30). Whoever believes in Christ, receives dynamis and pneuma, the force and spirit of the risen Christ - this transformative pneumatical activity is equated with God's creation: "if anyone is in Christ, the new creation has come" (2 Kor 5:17). In Patristics culminated the notion of an inner transformation of a believer in the idea of theosis. The typical phrase expressing the idea are the words we find in Fathers from Irenaeus to John of Damascus: "The Word was made flesh in order that we might be made gods." 12 That did not mean overcoming the metaphysical difference between human being and God - theosis meant for Fathers much more the fulfilment of human nature, its restoration to its original status of "image and likeness of God". This vertical transformation of human nature finds a horizontal counterpart in the relation of God's mercy to human history. So Irenaeus emphasizes, as against the Gnostics, the historical realization of mercy: God's Son embraced in himself the whole of human history so that people could also become God's sons and daughters. ${ }^{13}$

Scripture and theology think of grace as a processual eschatological reality. God's Kingdom is an eschatological happening for Jesus; for the Apostle Paul, grace is an eschatological saving happening in Christ; divinization is a process: divine life grows in the decisions of a redeemed human being for God on their way (status viae) towards their state of accomplishment (status termini). ${ }^{14}$ The work of grace takes place in a tension between "already" and "not yet". And here, in my opinion, lies the source of Lacoste's negative anthropology: the French thinker seems to favor the "not yet" pole of the eschatological happening so much that there is no space left for the transformation of the life of the believer this side of death. Liturgy brackets the world and the duties we find therein, but does not bring us to our eschatological fulfillment. The abyss between the transcendence of God and the immanence of human life seems to be the main feature of Lacoste's anthropology. God can overcome the abyss here and there, but that does not alter the anthropologia crucis ascribed to human beings. Just as the phenomenology of mercy seems to be almost missing in Lacoste's phenomenology of liturgy, it also undervalues, as I see it, the incarnational and, more generally, the Christological dimension of faith. Christ is not "among us" otherwise than in a (distant) event of reconciliation in the past and in a (distant) eschatological future. It is as if the event of Christ resided

10 See Ibid., 176.

11 See Lacoste, Note sur le temps, 124-126 and 201.

12 Athanasius, De incarnatione verbi, 54.

13 Irenaeus, Adversus haereses, III, 16,3; III, 18,1; IV, 28,1. For the exposition of the teaching on grace in Scripture and in Fathers see for example Ganoczy, Aus seiner Fülle haben wir alle empfangen, 13-148 and Mysterium salutis IV/2, 595-663.

14 See Schmaus, Die göttliche Gnade, 214. 
only in his crucifixion and resurrection, but not in his earthly life where the promises such as this one were made: "For where two or three are gathered in my name, there am I among them." 15 Lacoste postulates, as against Hegel, a split eschatology: the end of history which had begun but has not yet fully come. ${ }^{16}$ And history has nothing to say to the believer within the scope of this split eschatology. ${ }^{17}$ Believers exist in interim and history is not there for them to be made in faith: As believers, they are elevated from history. As I understand it, Lacoste risks an idea of God as foreign to history.

The motivation leading to a very cautious rendering of human possibilities in relation to God is most probably Lacoste's rejection of the Schleiermacherian heritage: The feeling of being created cannot be for us the sign of God's presence - Schleiermacher's feeling of absolute dependence can also be the feeling of our dependence on the "earth". ${ }^{18}$ Any religious apriori belongs to a pagan moment of facticity rather than to liturgy ${ }^{19}$ Lacoste deftly escapes the pitfalls of transcendental religious anthropology and saves God's otherness from an all too easy human appropriation thereof, yet his anthropologia crucis finds it difficult to give meaning to incarnational and transformative dimensions of faith. What brings someone to a religious conversion? How do believers find the peace bestowed to them by Christ? What meaning can faith give to our carnal earthly existence or how does it change the world in which we live?

\section{The more positive account of liturgy}

The rather negative rendition of human possibilities in relation to God was not the last word of Jean-Yves Lacoste. In his later works, he developed a more positive account of the phenomenology of liturgy and payed more attention to the communality of prayers, to love as a way of understanding the pre-eschatological presence of God, and to the sacraments, among other phenomena. ${ }^{20}$ In a way, these later texts follow a more positive theological anthropology as introduced in Lacoste's first book, Note sur le temps. This book offers a theological hermeneutics that allows for a more Christological shaping of our experience than does Experience and the Absolute: in Christ, the Absolute has demonstrated it is "capable of humanity" and left us with a "borderland" of the world and the Kingdom of God. ${ }^{21}$ Believers are invited to imitate Christ and struggle for holiness "on the margins of history". ${ }^{22}$ Although these more positive remarks about human possibilities in relation to God are restrained and do not describe a concrete way of transformation of either personal or communal life, they at least presuppose the possibility of human existence as an image of God. We may thus perceive the later Lacoste's texts as a phenomenological counterpart to the theological hermeneutics of the first book.

Let us now briefly outline the example of sacramental experience. In his article L'intuition sacramentelle, Lacoste states that all phenomena are perhaps equal in phenomenality, however not all of them possess the same phenomenality. What, then, is the manifestation proper to sacraments? The sacrament simultaneously veils and unveils the reality of grace that it signifies. It veils it, for we can see only bread and wine, the water

15 Matthew 18:20.

16 See Lacoste, Experience and the Absolute, 137-139.

17 "The man reconciled with God, who knows himself as such, expects nothing from history." Lacoste, Experience and the Absolute, 138.

18 See Lacoste, Experience and the Absolute, 206, footnote 8.

19 See Lacoste, Experience and the Absolute, 41-42. In this respect Lacoste follows Karl Barth and his rejection of religion as a mere human enterprise. Barth negated any possibility of examining a general religious experience and went still further than Lacoste by rejecting the very possibility of understanding human consciousness or human existence as something prior to the faith which arises from revelation. See Barth, Kirchliche Dogmatik I/1, 34-43.

20 See e.g. Lacoste, La phénoménalité de Dieu : Neuf études and Lacoste, Être en danger. In finding a certain shift in Lacoste’s rendering of the phenomenology of liturgy I am in line with Joeri Schrijvers, who defended the same thesis in his An Introduction to Jean-Yves Lacoste. There he writes (on p. 158) about “the shift in Lacoste's work from the parousiacal moment in light of the horizon of non-experience in the earlier work to the non-experience surrounded by and embedded in multiple moments of presence, peace and, perhaps, experience in the later work".

21 See Lacoste, Note sur le temps, 169.

22 Ibid., 193. 
of baptism and so forth; it unveils it, for there are also words added to the "element" of the sacrament and these words are performative ("I absolve you of your sins.") and indexical ("This is my body.") - and through "the eyes of faith", the believer sees them as an indicator of reality beyond empirical reach. The piece of bread becomes the boundary of history and the eschaton. ${ }^{23}$ But how can we give a phenomenological account of such a sacramental experience?

The Catholic theology of sacraments distinguishes between three realities that mark the process of the sacramental signification of grace: taking the eucharist as an example (i) the sign only (sacramentum tantum) - bread and wine and the words of consecration; (ii) reality and sign (res et sacramentum); that which both signifies and is signified - the true body of Christ; (iii) the reality of the sacrament, sacramental grace (res tantum, res sacramenti) - the union of the mystical body of Christ or a firmer incorporation in the mystical body. Hence, Lacoste's question is: Can we have a "sacramental intuition" of the res sacramenti? The answer is affirmative, yet with one precondition: as believers, we first have to constitute the "world of faith", a notion analogous to that of Husserl's "world of life" (Lebenswelt). We are not born into the world of faith; its constitution presupposes a specific knowledge and an education in it. The past experiences of our faith as well as the past experience of the church also add to its constitution. ${ }^{24}$ The world of faith is rooted in our own existence, in its "natural desire" of God that makes one homo capax Dei.

Now, when hearing the priest's words "This is my body ...", believers make a "remarkable reduction": They bracket sacramentum tantum (the visible bread and wine) and have a sacramental intuition of the res (God's presence). They say "Behold, the Lamb of God" or, when adoring the Eucharist, "my Lord and my God" - they do not adore bread and wine but God's presence. In this gesture they tear the body of the world apart (or they answer the rupture of the world made by Christ) and have a sacramental intuition. This intuition may not be an "originary presentive" and "legitimizing source of cognition" in the sense of Husserl's principle of all principles, ${ }^{25}$ for it presupposes cognition, that of the world of faith; yet for believers, bread and wine becomes simply the cloth between God's presence and themselves in their sacramental intuition. ${ }^{26}$

As we can see, Lacoste's positive account of liturgy finds room for God's presence in the life of believers and this presence does not entail their complete detachment from the common conditions of experience. Believers are still in the world of life while being in the world of faith - these two topologies of their existence do not exclude one another as was the case in Experience and the Absolute. The world of faith is not detached from the natural world, for desire of God is now deemed "natural" (but still carefully distinguished from the structures of any general "religious experience"). ${ }^{27}$ There is a certain incarnational motive present in this rendition of liturgy, yet the question remains whether God's presence also changes anything within the space outside of the coordinates of the world of faith. The wine and bread have now become but a thin veil between God and the believer, but does God's presence transform the whole of one's life? The liturgical chants and music bestow a "genuinely corporeal dimension" on the propositional truth of the Christian creeds ${ }^{28}$ but what remains of this incarnational moment when the mass is over?

The more positive rendition of liturgy in Lacoste's later work (and a theological justification of such a rendition in his first book) has found the means to secure the experience of the infinite God for the finite human being, but only in terms of a visit or a juxtaposition: God's kingdom and the secular world are still conceived as two separate realms. Eschatological reality finds a niche within the world where it can display itself under the veil of a sacrament or in the form of a liturgical chant but it does not really enter the historical context and does not transform it. Believers can only reach the "otherwise than history" in the experience of the sacrament. ${ }^{29}$ God's otherness serves as a hermeneutical tool that criticizes history in marking God's distance to it and enabling believers to experience that distance. Already in his first book Lacoste spoke

23 See Lacoste, "L'intuition sacramentelle”, 509-511.

24 Ibid., 517-520.

25 Husserl, Ideas I, 44.

26 See Lacoste, “L’intuition sacramentelle”, 522-524.

27 Ibid., 520-522.

28 Lacoste, La phénoménalité de Dieu, 223.

29 See Lacoste, Être en danger, 185-188. 
of the "demessianization of time" - there is no continuity between the pre-pascal time of hope and the post-pascal time of the memory of the pascal event, and the history after the Easter is "empty" ${ }^{30}$ Yes, it is empty so that the echo of God's words can resonate in it but it resonates there as a power foreign to history: "Theology can pursue its task only if it is not interested in the actual field of the present." ${ }^{31}$ This dualism of God's realm and secular human history, dualism founded in the future eschatology, is the final feature of Lacoste's whole oeuvre. Even if the "borderland" of the world and the Kingdom of God is proposed (as in Note sur le temps), it is still thought of as a tiny area on the margin of history, depending in the operation of the church - and nothing seems to be transformed out of the sphere of church operation, as if believers find themselves outside of the broader cultural and historical context in liturgy.

\section{The missing recontextualization of the Christian Tradition}

The relation between Christian tradition and the modern cultural context has been a burning issue in Christian theology ever since Christianity lost its monopoly on giving meaning to human existence. ${ }^{32}$ The work of Friedrich Schleiermacher, an imaginary adversary of Lacoste's phenomenology of liturgy, was driven by the question of how to draw the Christian religion nearer to its "cultured despisers". We may perceive Schleiermacher as the father of those modern theologies that try to find continuity between Christian tradition and the modern cultural context. These theologies have been labeled "correlation theologies" in the 20th century, with names such as Paul Tillich, Hans Küng, Edward Schillebeeckx and David Tracy associated with it. These theologies accept the modern emphasis on subjective experience and try to bring modern secular experience and the experience of Christian faith into a relation. Lacoste's phenomenology of liturgy may be seen as a part of a broad stream of theological thinking that criticizes correlation theologies for maintaining a relation between Christian tradition and cultural context at the expense of the particularity of Christian identity. These theologies stress the otherness of God and mark a rupture between the experience of Christian faith and cultural context. The Flemish theologian Lieven Boeve names as examples of such theologies the so-called Yale school around George A. Lindbeck, the movement of Radical Orthodoxy around John Milbank, and the work of some proponents of the so-called theological turn of French phenomenology, ${ }^{33}$ such as JeanYves Lacoste, Jean-Luc Marion and Emmanuel Levinas. ${ }^{34}$

Boeve himself tries to find a synthesis of both forms of theology: he wants to do justice both to the idea of God's otherness and to the conviction of correlation theologies that experience moves the Christian tradition toward its recontextualization. His proposal is to understand religious experience as an "interruption" (a term taken from J. B. Metz, who had used it as the shortest definition of religion ${ }^{35}$ ). Interruption means, first, the interruption of the continuity between Christian tradition and the cultural context, and marks the radical particularity and narrativity of the Christian identity. Yet we should not understand this interruption as a rupture between the tradition and context. There is, second, an interruption also within the Christian tradition, thanks to the inner connection between context and tradition - tradition moves in each new context and recontextualizes itself: "Theology of interruption can render its service by holding on to the intrinsic involvement of tradition with context in the interrupting experience of God. It is in very specific encounters of and occurrences that for Christians God comes interruptingly close, in daily life, in being faced with the poor and the other, even though for Christians this will often require exceptional attentiveness and hermeneutical care." ${ }^{36}$

30 See Lacoste, Note sur le temps, 161-165 and 155-158.

31 Lacoste, Note sur le temps, 157.

32 In the subsequent exposition, I am following the thought of the Flemish theologian Lieven Boeve; see his Interrupting Tradition and "Theology and the Interruption of Experience".

33 An ironic appellation given to several French thinkers by Dominique Janicaud in his book Le Tournant théologique de la phénoménologie française.

34 See "Theology and the Interruption of Experience", 27-31.

35 See Metz, Glaube in Geschichte und Gesellschaft: Studien zu einer praktischen Fundamentaltheologie, Mainz, Grünewald, 1977, 150, thesis vi.

36 Boeve, “Theology and the Interruption of Experience”, 39. 
Lacoste's phenomenology of liturgy suffers from decontextualization of the experience of Christian faith. It presupposes the "identical memory" and the "identical experience" that structure the community of believers across history. ${ }^{37}$ The pascal event and the eschaton bridge the history which has, after Easter, nothing to say to Christian existence. Yet salvation is not redemption from history but of history and has its historical consequences, although it finds its fullness only in the eschaton. ${ }^{38}$ Considering the deep political and environmental crises we are facing, we need a concept of the experience of Christian faith that is able to recontextualize the Christian tradition in our current situation. God's grace carries out its transformative work in the concrete historicity and materiality of life. I would like to sketch two counterexamples to Lacoste's rather non-historical treatment of the experience of Christian faith. Both examples speak more to the "already" pole of the Christian eschatology than does Lacoste, as they try to recontextualize the (pre)eschatological experience of the community of believers within concrete historical and cultural coordinates.

\section{William Cavanaugh: The world in a wafer}

The first example offers a different hermeneutics of the sacramental experience than that of Lacoste, as it places the experience of the sacrament (the Eucharist) amidst the world. It comes from the American theologian William Cavanaugh, who works mainly in the field of political theology, which basically means for him searching for the new political imagination stemming from the experience of Christian faith: "The church as a different type of politics is not a place to which to withdraw, but a resource for imagining a different world." ${ }^{39}$ Cavanaugh, similarly to Boeve, does not want to suppress the particularity of Christian identity and the "interruption" that the experience of God's nearness means in respect to the prevailing (secular) cultural context; yet he reinvests this interruption in the actual sociohistorical conditions believers find themselves in and shows how the sacramental experience can transform the way they understand the world in which they live.

Already the title of his article The World in a Wafer: A Geography of the Eucharistas Resistanceto Globalization suggests the connection between the sacramental experience and the broader culture. Cavanaugh argues that globalization does not bring about universality in terms of catholicity; he wants to oppose to it the Eucharist as a "truly Catholic practice of space and time"..$^{40}$ Cavanaugh draws on Michel de Certeau's distinction between "itineraries" and "maps": While pre-modern itineraries told "space stories", for example giving pilgrims advice on where to pray, where to sleep, and so forth, modern maps work with abstract places without the intervention of people. The universal perspective of modern mapping allows one to see the entirety of space simultaneously and uniformly. The project of the modern nation-state relies on such mapping, for it subsumes all local particularities under the supervision of one directing center. Yet the current global economy has brought even the institution of the nation-state to crisis, for transnational economy is out of the control of any government. Nations and localities are now merely competing against each other to attract constantly shifting capital investments and are subjugated to institutions such as the World Trade Organization.

Modern mapping reached the global view suggested by the metaphor of a "global village" and brought to practice universal corporate culture and the universalization of consumption. Although global mapping tries to bring about the illusion of diversity - diversity of local traditions and tastes brought to a single global market - consumers are in fact detached from all particularities, as these particularities are interchangeable, and the main task of a global economy is the production of desire (for anything) itself. Globalization entails the dominance of universality and creates a decentered subject, dispersed among interchangeable goods and their ephemeral images.

What, then, has the Eucharist to offer against the global deposition of the local and the subjective? According to Cavanaugh, it is an idea of catholicity as opposed to the universality of global mapping. Although both words are rendered equivalent in modern English, "universal” suggests spreading out and

37 See Lacoste, Note sur le temps, 164.

38 The Apostolic Father Ignatius of Antioch was one of those who claimed that the resurrection of Christ took place in history for the salvation of history and time. See Ign. Eph. 1, 7, 19, 20.

39 See Cavanaugh, "Re-Anarchizing Christianity".

40 Cavanaugh, "The World in a Wafer”, 182. 
"catholic" suggests gathering together. The Eucharist is the center around which the church gathers, yet it is a decentered center: Local churches have their own rites, music and liturgical spaces to celebrate it, and the "catholic church" is not a permanent place but a diaspora. And no matter how scattered the local churches are, the Eucharist they celebrate is gathered into one, since it represents the whole body of Christ. Ancient Roman liturgy expressed the unity of the body of Christ in a particular way: Particles of the host from the papal Mass were sent out to priests celebrating Mass in other localities - but each particle presented the whole of the body of Christ. The Eucharist overcomes the dichotomy of universal and local, for "one becomes more united to the whole the more tied one becomes to the local." ${ }^{41}$

The Eucharistic community transcends natural and social divisions - in Paul's words, "In Christ there is neither Jew nor Greek, neither slave nor free, nor male and female." 42 Yet in history the Eucharistic community also excluded some, for example Jews. As a defense against an exclusivist and conservative conception of the church fixed to a certain location and its given social structure, Cavanaugh proposes another type of gathering: Catholica conceived as "a story which performs certain spatial operations on places" ${ }^{43}$ The City of God uses this world in its pilgrimage to heaven; the community does not need to move - as the global market wishes from its subjects - but instead the whole universe comes to the Eucharist that tells a story of cosmic proportions. The eschatological dimension of the Eucharist unites the church of all times and places in eternity.

The Eucharist reverses the logic of consumption: The one consuming the Eucharistic bread and wine is absorbed into the body of Christ. The world has changed for the one who has been consumed by the body of Christ - they are able to see Christ in the homeless person around the corner. In the globalized world diverse localities compete against one another; in the body of Christ barriers are overcome without competing: "If one member suffers, all suffer together; if one member is honored, all rejoice together." ${ }^{24}$ But the Eucharist, according to Cavanaugh, also resists a superficial global sentiment that overlooks the barriers where they really are (between the rich and the poor, the global North and the global South and so forth). When Paul discovered the humiliation of the poor by the rich during the Lord's Supper in Corinth, he wrote: "Whoever, therefore, eats the bread or drinks the cup of the Lord in an unworthy manner will be guilty concerning the body and blood of the Lord." ${ }^{45}$ The Eucharist can obtain various social interpretations following the current conditions in which the local community lives.

We can now see the difference between the way Lacoste and Cavanaugh give meaning to the sacramental experience. In Lacoste, believers adore the God's presence when receiving the Eucharist; in Cavanaugh, they are transformed. Adoration requires a certain distance between the one who adores and the one who is adored, the distance of seeing (be it in a metaphorical way seeing by the eyes of faith as Lacoste speaks of "sacramental intuition"); transformation requires immediacy, that of eating. Cavanaugh describes the transformation in this way: "In the Eucharist the particular is of the utmost importance, for this particular piece of bread at this particular place and time is the body of Christ, and is not merely a pointer to some abstract transcendent standing behind the sign. In the Eucharist there is a hypostatic union between reality and sign, res et sacramentum. Christ saturates the sign, such that consumption of the Eucharist identifies the consumer with God." ${ }^{46}$ This first transformation, brought by Christ, then transforms the way believers signify themselves, their community and the world they live in: believers find themselves in a community that transcends natural and social divisions ("in Christ neither slave nor free, nor male and female"); the community becomes the place of a story of cosmic dimensions no matter how big/small, rich/poor, etc. the community is - as such it represents an alternative to the dominant discourse of globalism; believers are able to give different meaning to the world they live in (they are able to see Christ in the homeless person around the corner); believers themselves become sensible to different meanings the concrete celebration of the Eucharist can obtain..$^{47}$

\footnotetext{
41 Cavanaugh, "The World in a Wafer”, 190.

42 Galatiens 3:28.

43 Cavanaugh, "The World in a Wafer", 191.

441 Corinthians 12:26.

451 Corinthians 11:27.

46 Cavanaugh, "The World in a Wafer”, 192.

47 Cavanaugh gives a moving example of the last case: When Fr. Rutilio Grande was killed by a government-sponsored death squad in El Salvador in 1977 after preaching about the Eucharist as a common meal for both rich and poor, the Archbishop Oscar Romero declared that only one Mass, the funeral Mass, would be celebrated in the Archdiocese that Sunday. All the believers were brought to one table to experience that there is no real division among rich and poor in Christ. See Cavanaugh "The World in a Wafer", 194.
} 


\section{Robert Kalivoda: Present eschatology and the idea of human emancipation}

As Lacoste's intellectual work traverses the (supposed) border between theology and philosophy, I have chosen to take my second counterexample of the historically and culturally embedded interpretation of the experience of Christian faith from the thought of Robert Kalivoda, the Czech Marxist thinker whose work is devoted to the philosophy of history and its Christian origins. It is an example of the present eschatology at work in interpreting the experience of Christian faith and, as such, represents a counterposition to Lacoste's future eschatology. As we move with Kalivoda mainly to medieval Christianity, we are coming back to a time when the Christian religion retained its monopoly on giving meaning to human existence. This monopoly, of course, is not something we should ever wish to come back. It is displayed here first to show the transformative historical strength the Christian experience can acquire and, second, to remind us that the heritage of Christian experience is also present in secular thinking and secular culture in a prominent way. Kalivoda, as a secular humanist, thinks rather of the humanization of God than of the human being becoming god (theosis).

Kalivoda's philosophy of history stands in a philosophical tradition whose prominent example is Hegel's Phenomenology of Spirit. Lacoste himself to a certain degree respects this other "phenomenology" as a rather modest type of realized eschatology. He finds Hegel's present eschatology theologically consistent (based on the fact of the reconciliation on the Cross), even if it neglects the act of the resurrection and the future eschatology anchored within it. ${ }^{48}$ Kalivoda is interested precisely in those historical phenomena in which the "already" pole of Christian eschatology was absolutized, first of all in the specific development within medieval millennialism and utopianism.

Yet before we come to it, something should be said about the very idea of historicity. The concept of human society as an historical unit determining its fate through free practice grew in the convergence of the ancient polis and the Jewish and Christian faiths. ${ }^{49}$ Augustine is the classic figure of this synthesis. We now put the contribution of the ancient polis aside and devote attention to the religious source of the idea of historicity. Jewish and Christian (and, of course, Islamic) theologies rendered people as the subjects of choice and free action, which has far-reaching ramifications. In human life, what is at stake is redemption - that is, the possibility of partaking in God's reality, which transcends the determinateness of earthly existence or, more precisely, which fills earthly reality with the ontologically other reality of God. Human action thus potentially transcends the given order of the cosmos and changes the cyclical time of cosmic events in human historical time in which decisions for and against community with God encounter one another. The Old Testament "people of God", ${ }^{50}$ the image of the church as the "body of Christ" which we find in the Apostle Paul, ${ }^{51}$ Augustine's "City of God" living in tension with the "Earthly City", are the ideal forms of a historically existing society that in the understanding of its faith breaks through the closed space-time world and opens it to the future fullness of life with God or, more precisely, participates in such breaking through whose real subject is God.

This eschatological origin of historical thought also lies in the foundation of the modern concept of the historical emancipation of humankind. In the remaining part of my paper I will attempt to outline how Robert Kalivoda delineates this transformation of eschatological imagination into the program of the real transformation of human society. Karl Marx placed the idea of "human emancipation" against mere "political emancipation" in the liberal state in his work On the Jewish Question: However obviously political emancipation (i.e. the equality of all citizens before the law and a religiously neutral state) signifies considerable progress as against the previous historical stage, it does not signify the complete liberation of people, for the citizen of the liberal state is, according to Marx, free only by a "detour", by means of the state. Although the state guarantees everyone equal rights, at the same time it allows enormous differences

48 See Lacoste, Experience and the Absolute, 135-136.

49 For the concept of historicity in ancient Greece see Arendt, The Human Condition, 181-188.

50 For example Numeri 11:29 or Book of 1 Samuel 2:24.

51 1Corinthiens 12:12-14, 12:27; Ephesians 4:1-16. 
in ownership, education and employment to operate in civil society, which in fact bind a large part of society. ${ }^{52}$ It is only human emancipation that is the true liberation of "all human [physical and mental] senses and qualities," ${ }^{53}$ in the "realm of freedom", thus in the free self-creation of the person in society, in which the estrangement of people from their own human potential and, thereby, the mutual estrangement of people, disappears.

The idea of "human emancipation" thus primarily assumes a conflicting relationship with the current reality, the idea of a better organization of human society that people can attain themselves. Kalivoda refers to the utopian idea of the immediate establishment of such a societal organization as "revolutionary romanticism". According to him, the genealogy of its modern form has its beginnings in Christianity, especially in the Christian non-conformism of various reform movements and sects. Early Christian chiliasm is in this concept the first manifestation of "plebian romanticism", which transforms the concept of the primal lost paradise into the futurological ideal of God's thousand-year rule on earth..$^{54}$ In this projection, the basic scheme of the romantic attitude is reflected onto reality: estrangement from the good human substance and the return to it. In the Patristics, the Biblical idea of the primal paradisiacal state is enriched by the Stoic ideal of human nature, based on a universalistic idea of original human freedom and equality. According to Kalivoda, the first historical variant of this category of estrangement arises in the Stoic-Patristic distinction between the absolute natural law applicable in the original state of freedom (before the Fall), and the relative natural law applicable in the current state of unfreedom (after the Fall). ${ }^{55}$

Medieval heresy assumes this romantic scheme and fills it with a social content. ${ }^{56}$ For Kalivoda, the first climax of this development is the Czech Hussite revolution in the 15th century. ${ }^{57}$ The Hussite movement was to a large extent a Eucharistic movement: A number of its requirements crystallized around the entitlement to accept both kinds of Eucharistic elements; the lay chalice became the emblematic symbol of the movement. The democratization of accepting the Eucharistic elements - that not only priests, but all believers are entitled to accept the bread and wine - became the distinguishing mark of the movement, which required a broad reform of church life and the life of feudal society as a whole.

Medieval folk heresies assume certain theological (and theosophical) concepts, and these movements themselves have at their center educated creative intellectuals; therefore, in historical development, a reciprocal notional exchange of material between "learned" and "folk" environments occurred..$^{58}$ Indeed, this exchange enables Kalivoda to follow the effect of theological and philosophical concepts in history. The line of "heretical Platonism", in which the heritage of Platonism and Neoplatonism is intermixed with Christian non-conformism, thus arrives at the forefront of attention alongside biblically-founded chiliasm. Prior to the Stoa, Platonic speculative dialectic expressed a conflicting tension between substance and its degradation and raised this tension from a human to an ontological level. ${ }^{59}$ We thus find in Plato a romantic scheme similar to early (and later heretical) Christianity, though in the reverse order. The conflicting tension with given reality leads Plato to postulate the ideal city in which human substance, represented by ruling philosophers, is exalted: through their rational government, the spiritual absolute is lowered to sensory reality, is uplifted from it and liberates from it. Kalivoda is of the impression that the Stoic idea of human nature is the democratization of the Platonic "exalted" substance of the human being, now applied to the entire human race.

52 Marx, On the Jewish Question, 146-152.

53 Marx, Manuscripts of 1844, 300.

54 Kalivoda introduces his concept of the historical development of emancipation ideas in the greatest detail in the study "Marxismus a libertinismus".

55 See Kalivoda, “Marxismus a libertinismus”, 108-109.

56 The main inspiration for Kalivoda here is the renowned work by Ernst Troeltsch, Soziallehren der christlichen Kirchen und Gruppen.

57 Kalivoda's largest work, Husitské myšlení, is focused on the ideology of the Hussite revolution and its historical-philosophical assumptions. The first edition of the book, under the title Husitská ideologie, was published in 1961. The second, revised edition of the book was prepared after Kalivoda's death from the manuscript of the planned second edition from the late 1960s, from other author revisions of the text and from the German edition (Revolution und Ideologie. Der Hussitismus. Köln a. R.: Böhlau, 1976) of the book by Eva Věšinová and Jan Kalivoda under the title Husitské myšlení, Filosofia, Praha 1997.

58 See Kalivoda, Husitské myšlení, 80-81.

59 See Kalivoda, “Marxismus a libertinismus”, 111-113. 
At the level of ideas, the line of "heretical Platonism" is an historical movement which, according to Kalivoda, is consistent with the movement of the historical emancipation of the human being; philosophically, it constitutes a movement from idealism and theism to immanentism, pantheism and materialism. It begins in the 12th century with Amalric of Bena and the Amalrician sect, and Kalivoda ranks with it, for instance, the teaching of the Heresy of the Free Spirit, the pantheistic metaphysics of Meister Eckhart, Wicliffe's extreme Platonic realism conceived as a reform program for the rectification of the church and, at a later date, the Neoplatonically-founded concept of the rectification of the world in Comenius. In the interpretation of the Czech thinker, this line leads all the way to the Hegelian negative dialectic and Feuerbach's and Marx's teaching on the human. The movement from idealism to pantheism and materialism primarily means that the ideal characteristics that were attributed to the superterrestrial world or, more precisely, humans - to the extent to which they participate in it - are gradually drawn towards the terrestrial world and the humans in it. This is not primarily a desacralization of reality, but rather its saturation with the characteristics that religious faith and rational speculation conceived as divine thanks to their origin in the transcendent sphere. In the course of history, orientation to this world became dominant in the religious dialectic of this and the other world, but its values have been saturated by those attributed originally to the superterrestrial world. For example, the conviction of the irrevocable freedom and sovereignty of humans is the historical secularization of God's attributes; the chiliastic concept of God's intervention and Christ's thousand-year rule eventually gave way to the revolutionary activity of the people, but the latter has now been endowed with an absolute moral sanction. With the diminishing of transcendence, phenomena in the order of immanence, saturated with the absolute character of being conceived originally as transcendent being, are intensified.

What role did chiliasm thus play in the development of the idea of the historical emancipation of humans? Chiliasm gave folk heresy movements the philosophy of history, in which the establishment of harmonious social relationships is conceived as a necessity endowed with absolute, divine sanction. In substance, the medieval church worked with the Augustine philosophy of history: Humankind is moving towards the superterrestrial kingdom of perfection (or the infernal curse) - the earthly life of society is but a preparation in which humans are subjected to necessary woe as a result of original sin. In contrast, chiliasm returns to the old Christian idea of a human paradise on earth that was the fruit of early apocalyptic Christianity. Chiliasm is the historicization of Christian eschatology - paradise after death has been exchanged for the closing epoch of the earthly history of humankind.$^{60}$ The most significant teaching of this type is that of the Cistercian monk Joachim of Fiore, who at the close of the 12th century formed a triune philosophy of history, in which, after the time of the Father's rule (the Old Testament, the state of slavery) came the period of the Son's rule (the New Testament, the state of freedom), and in the near future (specifically the year 1260), the period of the Spirit's rule is apparently to come, in which people will be directly enlightened by God's wisdom, everyone will become friends, and servitude will disappear. This harmonious organization of the society of enlightened people is to last until the world ends. The Joachimistic philosophy of history penetrates into the Amalrician teaching, as it does into the later teaching of the Heresy of the Free Spirit. Indeed, the permeation of chiliasm with the teaching of the Free Spirit enabled the generalization of "freedom and perfection" to the whole of humankind in the new historical epoch, as is documented by the teaching of the group of Konrad Kannler from the end of the 14th century or the Brussels sect "homines intelligentiae" from the beginning of the 15th century. Yet, in the same way as Dolcin's chiliastic system or folk prophecy (Kalivoda names Sibyl's prophecy and Rupercissa's prophecy), ${ }^{61}$ the Brussels sect further intensifies the anti-clerical social content of chiliasm: The goal becomes the liquidation of the hierarchical church and the establishment of the "Apostolic state", in which there will be no priests of the old church, lords or knights, and feudal rent will disappear.

60 In addition, Kalivoda argues that chiliasm is the original form of Christian eschatology: The Chiliastic elements in Paul's epistles, John's revelation, and the Church Fathers until Augustine, according to him, testify that Christianity has a chiliasticapocalyptic basis. See Kalivoda, Husitské myšlení, 261-263.

61 Sibyl's prophecy is of German origin; the author of the second prophecy is the French Franciscan John of Rupercissa, whose brief work was written around 1349. 
Chiliasm counts on God's decisive intervention, which will remove the tainted church and establish a new form of interhuman relationships. Kalivoda's work on Hussite thought follows development of ideas in the most radical Hussite branch - in peasant-plebian Tábor - so as to find in it a surpassing of the orientation to the miraculous establishment of new social relationships and the transformation of the expectation of God's intervention in human action. The issue of Hussite ideology and the Hussite humanization of God is, according to Kalivoda, Pikartian and Adamite pantheism. ${ }^{62}$ The closing Adamite phase of the development of the radical Hussite forces definitely dissolves God into human activity or, more precisely, into "good people", and thus grows into a natural concept of the world, as attested to, for example, by this sentence from Vavrinec's paper on the Adamites: "They call the heavens above them the roof and say that God is not in heaven or devils in hell, but devils are in evil people and God in the good." ${ }^{63}$ The natural relation to the world and to one's own senses appeared also in the Adamite transformation of the Lord's Supper, which followed the Pikart concept of the Supper as a real, earthly fulfilment and shifted it still further to a form of a folk celebration of sorts, which probably also included the erotic area. "God's Law", the religious-notional guideline of Hussitism, fused with the law of nature, which, however, thus gained a high moral sanction and acting according to it gained an absolute moral obligatoriness. The Adamites thus transformed chiliasm into fulfilment of the ideal of the earthly happiness of humans in a justly organized society that abolished all feudal obligations, rents and hierarchies. ${ }^{64}$

The Pikart-Adamite left represented the most radical segment of Hussitism, against whom the burgher opposition in Tabor itself turned. Hussite military leader Jan Žižka organized expeditions in the course of 1421 that physically eliminated Pikarts and Adamites. According to Kalivoda, the first European variant of Jacobinism, i.e. the revolutionary idea of the liberation of all people, was thus eliminated. This idea passed through numerous modern revolutions until it finally gained the new modern form of the Declaration of the General Rights of Man and the idea of social autonomy, and was further realized in the emancipation struggles of the 19th and 20th centuries.

Although the most radical segments of Hussitism were defeated, the Hussite revolution as such was victorious; as early as the 15th century, the coexistence of the new Hussite "Utraquist" church, in which both bread and wine were accepted, and the old Catholic Church created a situation of religious tolerance in the Czech Kingdom, historically the first in Europe. According to the agreements of the Basel Compact from 1436 and to other laws, religious freedom and tolerance of Utraquism and Catholicism applied for every individual without exception, thus including the subjected people. Regardless of where inhabitants of the kingdom lived, they could go to the church that practiced their faith. The Czech Lands surpassed the rest of Europe inasmuch as they did not accept the principle of cuius regio, eius religio ("whose realm, his religion"), and in their individualistic concept of religious freedom foreshadowed modern development. ${ }^{65}$

Kalivoda as a Marxist thinker was primarily interested in the most radical segments of the Hussite revolution, whichalso enabled him to draw a kind of idealized picture of the process of historical emancipation as a linear progress of the secularization of Christian eschatology. I believe that the defeat of the radical segments of the Hussite revolution and the victory of its moderate segments problematize this ideal picture and suggest a more dialectic conception of the transformative encounter of God's transcendence with the immanence of human history. The radical program of ecclesiastical and social reforms arose from the historicization of Christian eschatology, by the subjection of the church and society to the ideal criteria of God's kingdom on earth. But the transfer of originally transcendent realities into the earthly immanence of real history entails the loss of their original purity, their absolute character. The unavoidable relativization of ideas of the ideal society that accompanies their transfer from the eschatological perspective to the level of historical emancipation should also lead us, as I understand it, to a certain correction of Robert

62 The Pikarts and Adamites were the most radical segments of the Hussite movement, which retained its chiliastic vision until the end of its existence.

63 The paper originated from the Husitské kroniky by Vavřinec of Březová, cited in Kalivoda, Husitské myšlení, 257-258.

64 See Kalivoda, Husitské myšlení, 178-261.

65 Kalivoda payed attention to the post-revolutionary development in the Czech Kingdom in his later texts, collected in his book Husitská epocha a J. A. Komenský. 
Kalivoda's reductive concept, which delineated the movement from idealism and theism to pantheism, materialism and ultimately atheism as the normative concept of the emancipation of humankind. Indeed, the impossibility of the full realization of transcendent realities in the immanence of history leaves in validity a "transcendent" remainder which cannot be reduced, and which has once again to become the driving force in the inexhaustible process of the dialectic of the divine and the human. ${ }^{66}$ There will always be needed the "interruption" of the historical by the eschatological, even if the historical is an endeavor for human emancipation - the environmental crisis we are facing now is a good example of such a need. Yet at the same time and against Lacoste we claim also the need to reinvest this interruption in the way we as Christians or people of religious faith imagine the world we live and act in and, in doing so, shape history.

\section{Conclusion}

Jean-Yves Lacoste's phenomenology of "liturgy" approaches with a careful and subtle investigation of the possibility of the encounter of God and human being. Although Lacoste replaced the original, rather negative evaluation of these possibilities with the more positive assessment of his later development, his main departure point has not changed: It is a rejection of a religious apriori on the side of the human being and emphasis on God's transcendence and otherness. Such a phenomenology of the experience of Christian faith stresses the particularity of Christian identity and marks a rupture with secular experience and secular culture. I have tried to show that Lacoste's attitude is one-sided because it saves God's otherness and the transcendence of eschatological reality at the expense of the possibility of a transformation of the believer.

I have also sketched two counterexamples to Lacoste's position that allow for the experience of Christian faith to recontextualize the Christian tradition within the concrete cultural and historical situation of believers. In the first example, I sketched the manner in which William Cavanaugh recontextualizes the understanding of the sacramental experience in view of globalization: The Eucharist overcomes the dichotomy of the local and the universal, reverses the logic of consumerism, and brings a comprehension of the world that is an alternative to the dominant discourse of globalism. This hermeneutics of the sacramental experience mainly leaves room for the transformation of believers in terms of the transformations of their historical and societal imagination. In the second example, I described the manner in which Robert Kalivoda interprets the transformation of Christian eschatological ideas in a program of real social changes: Christian eschatological thought is not only at the root of the modern concept of historicism, but also at the root of the idea of the emancipation of humankind that is realized in history. Kalivoda shows this in more detail with the specific historical example of the Hussite revolution in the 15th century.

Kalivoda's philosophical thought, unconstrained by Christian orthodoxy, represents an interesting counterpart to theological investigations of the encounter of God and human being. What Kalivoda is looking for is not theosis, the divinization of the human being, but the humanization of God. It can give us a better picture of the transformative power of the experience of Christian faith because it shows that the dialectics of God and human being can operate in both directions: human being is becoming God (and the community of believers is trying to live as if God's kingdom is either near or even here); God is becoming human being or more precisely the community of believers dare to appropriate and perform the transformative power originally ascribed to God. It is this dialectics of the divine and the human that has given rise to the course of history as we understand it today - as the free pursuit of common aims open to historical progress. Although this notion of history has meanwhile been secularized, it is important, at least from the Christian perspective, to keep this dialectics running in our thinking and acting so that history remains open to free reshaping and does not merely follow blind processes of any kind (economical, biological, cosmic etc.). The automatism of those processes and the "given" state of things need to be constantly interrupted by the eschatological imagination. The dialectics of the divine and the human is based in terms of Christian experience on the double dimension of Christian eschatology - on its "already" and "not yet". The phenomenology of

66 This therefore means that the dialectic of the divine and human need not be conceived of as a negative dialectic, as is the case in Kalivoda. 
"liturgy" of Jean-Yves Lacoste represents thinking that favors the future dimension of eschatology (and risks the idea of God absent in history after Easter), whereas Robert Kalivoda's hypothesis of the historicization of eschatology as a source of the idea of human emancipation favors the present dimension of eschatology (and risks the idea of God who has gradually disappeared completely) ${ }^{67}$ The political theology of William Cavanaugh, only very briefly sketched in this paper, represents the middle position, in which both poles of Christian eschatology meet without merging in reshaping our historical and societal imagination. All three positions are in their own ways trying to give an account of the complex logic that presides over the encounter of God and human being, and also lead to different theologies and philosophies of history, as the relation towards eschatological reality is the cornerstone of these theologies and philosophies. It is clear from this paper that I side more with the second and the third positions, because I find them more capable of meeting the challenges we currently face.

Yet my preference, of course, does not diminish the subtlety and originality of Lacoste's work, which aims mainly at the possibility of an individual encounter of human being and God here and now. Nevertheless, the relation to the eschatological reality is also decisive for Lacoste's phenomenology of "liturgy": the emphasis put on the future eschatology shapes the very phenomenality of that encounter and leads to the impression that the "here and now" of the encounter with God seems to be isolated from the rest of one's life and human history.

The second point I want to make in conclusion concerns the interplay of the ontological and the hermeneutical in the experience of Christian faith and in the description of its transformative power. The original idea of theosis, as shaped by the Greek Fathers, worked with human participation in the divine energeis or dynameis, which were ontological categories; the Fathers considered the Eucharist "the heavenly bread" in quite a straightforward way; the time after Jesus Christ was simply the period of the Son's rule for Joachim da Fiore, with the period of Spirit's rule soon to come according to him. Modern thinking does not work so easily with such massive ontological transformations and tends to combine the ontological aspect with the hermeneutical: ${ }^{68}$ How can we discern God acting in our lives? How is God present in the Eucharist? How can we apply the eschatological perspective to the past and the present? ${ }^{69}$ I have tried to show in this paper three different attitudes towards giving meaning to the sacramental experience. In Lacoste, believers have a "sacramental intuition": when celebrating the Eucharist and hearing the priest's words "This is my body ...", they make a "remarkable reduction" (also called "liturgical" or "eschatological reduction" in his other works) and bread and wine becomes just the cloth between God's presence and the believers. This experience requires previous learning of how to inhabit the "world of faith". However close believers find themselves to God's presence in that experience, they do not seem to be fundamentally transformed by it, and neither does their understanding of the secular world. In Cavanaugh, the believer who eats the consecrated bread is identified with God, which brings about a transformation of the way they signify themselves, their community and the world they live in. The hermeneutical dimension of the sacramental experience plays an important role not only in the preparation for the celebration but also in the life after because the celebration of the Eucharist has its (hermeneutical) consequences for the life of the believer within the secular world.

Robert Kalivoda offers a certain contra-reading of the sacramental experience as testified by the Hussite revolution in the 15th century. The Hussite movement was originally a sacramental movement

67 It is Kalivoda's modern-day interpretation of a historical development within specific medieval streams of thought (and action) that makes it possible for us to speak about present or realized eschatology in his case. The opposition of future eschatology and realized eschatology belongs to the conceptualization of modern theology. Medieval millennialism, which came under Kalivoda's scrutiny, is in itself a complex phenomenon with a set of eschatological teachings. Kalivoda follows that line of chiliastic apocalyptic thought in which the heated awaiting of the "near" coming of God's kingdom changes into the "now" of revolutionary action. To understand such a process as a process of human emancipation is a modern interpretation. 68 This assumption does not imply that the hermeneutical dimension was missing in the theologizing of the Fathers. It merely underlines the assertiveness of the ontological perspective.

69 Ana-Maria Petrache, in her article "The Transformative Impact of Eschatological Narratives: A Reflection on the Theology of History", describes how Gaston Fessard, Jürgen Moltmann and Ioannis Zizioulas in their works read the timeline in reverse, from the future to the present and the past. 
driven by a "spiritual hunger" for the laypeople taking in both kinds, bread and wine. The centrality of the Eucharist for experiencing Christian faith enabled the Hussites to use the symbol of the chalice and the demand for its democratization as the symbolic center of both their doctrine and their social reform endeavor. Kalivoda, interested in the idea of the humanization of God, mainly follows those Hussite streams that underwent an ideological development from theism to pantheism and a consequent deconstruction of the church doctrine of the Eucharist: The Adamits and the Pikarts broke with the teaching of transubstantiation; by putting down the transubstantiational miracle they have also put down, according to Kalivoda, the institutional power of the medieval church. The Lord's Supper was consequently changed into a real, earthly fulfilment and shifted still further to a form of folk celebration. The most radical parts of the Hussite revolution underwent a revolutionary change in the understanding of both the Eucharist and the social world. These changes were founded in the Hussite transformation of the chiliastic vison into present, realized eschatology.

Kalivoda's treatment of the historical development of the Eucharistic tradition can also indicate to us that the transformative power of the human encounter with God shapes secular culture too, as he sees the modern striving for human emancipation as the outcome of a complex development within the tradition of Biblical religion. Theologically speaking, it also reminds us that by the act of a contingent, historical incarnation God entrusted themselves to the open process of human understanding of who God is and what the different ways they encounter us are, and that this process of understanding is, of course, fallible to the extent it is a human understanding.

\section{References}

Arendt, Hannah. The Human Condition. Chicago: The University of Chicago Press, $1998^{2}$.

Barth, Karl. Die Kirchliche Dogmatik I/1: Die Lehre vom Wort Gottes. Prolegomena zur Kirchliche Dogmatik. Zollikon-Zürich: Evangelischer Verlag, $1947^{5}$.

Boeve, Lieven. Interrupting Tradition: An Essay on Christian Faith in a Postmodern Context. Grand Rapids, MI: Eerdmans, 2003.

Boeve, Lieven. “Theology and the Interruption of Experience.” In L. Boeve - Y. de Maeseneer - S. van den Bossche (eds.), Religious Experience and Contemporary Theological Epistemology. Leuven: Peeters, 2005, 11-40.

Cavanaugh, William. "Re-Anarchizing Christianity." https://politicaltheology.com/re-anarchizing-christianity/ accessed 2019.08.01

Cavanaugh, William. "The World in a Wafer: A Geography of the Eucharist as Resistance to Globalization.” Modern Theology 15:2 (1999), 181-196.

Černý, Jan. "Experience and the Absolute." Communio Viatorum. 48:2 (2006), 175-180.

Ganoczy, Alexandre. Aus seiner Fülle haben wir alle empfangen: Grundriß der Gnadenlehre. Düsseldorf: Patmos, 1989.

Husserl, Edmund. Ideas Pertaining to a Pure Phenomenology and to a Phenomenological Philosophy: First Book: General Introduction to a Pure Phenomenology. Hague - Boston - Lancaster: Nijhoff, 1983.

Janicaud, Dominique. Le Tournant théologique de la phénoménologie française. Paris: Eclat, 1991.

Kalivoda, Robert. "Marxismus a libertinismus.” In Robert Kalivoda. Moderní duchovní skutečnost a marxismus, Praha: Československý spisovatel, 1968, 103-148.

Kalivoda, Robert. Husitská epocha a J. A. Komenský. Praha: Odeon, 1992.

Kalivoda, Robert. Husitské myšlení. Praha: Filosofia, 1997.

Lacoste, Jean-Yves. Experience and the Absolute: Disputed Questions on the Humanity of Man. New York: Fordham University Press, 2004.

Lacoste, Jean-Yves. Être en danger. Paris: Cerf, 2011.

Lacoste, Jean-Yves. “'L'intuition sacramentelle.” Revue Théologique de Louvain 42:4 (2011), 496-525.

Lacoste, Jean-Yves. La phénoménalité de Dieu: Neuf études. Paris: Cerf, 2008.

Lacoste, Jean-Yves. Note sur le temps: Essai sur les raisons de la mémoire et de l'espérance. Paris: PUF, 1990.

Marx, Karl. “On the Jewish Question.” In Karl Marx, Frederick Engels. Collected Works: Volume 3. Marx and Engels 1843-1844. Moscow: Progress Publishers, 1975, 146-174.

Marx, Karl. "Economic and Philosophic Manuscripts of 1844." In Karl Marx, Frederick Engels. Collected Works: Volume 3. Marx and Engels 1843-1844. Moscow: Progress Publishers, 1975, 229-346.

Mysterium salutis: Grundriss heilsgeschichtlicher Dogmatik. Band IV/2: Das Heilsgeschehen in der Gemeinde. Gottes Gnadenhandeln. Einsiedeln - Zürich - Köln: Benziger, 1973. 
Metz, J. B. Glaube in Geschichte und Gesellschaft: Studien zu einer praktischen Fundamentaltheologie. Mainz, Grünewald, 1977.

Petrache, Ana-Maria. "The Transformative Impact of Eschatological Narratives: A Reflection on the Theology of History." Hermeneia 22 (2019), 93-99.

Schmaus, Michael. Katholische Dogmatik: Dritter Band. Christi Fortwirken bis zu seiner Wiederkunft. Zweiter Teil: Die göttliche Gnade. München: Hueber, $1965^{6}$.

Schrijvers, Joeri. An Introduction to Jean-Yves Lacoste. Burlington, VT: Ashgate, 2012. 